\title{
The Application of the Multi-criteria Analysis in Evaluating of the Road Designs
}

\author{
LJUBIŠA T. KUZOVIĆ, Engineering Academy of Serbia, Belgrade, \\ BORIVOJE LJ. ALEKSIĆ, S-projekt, Belgrade \\ DRAŽENKO N. GLAVIĆ, University of Belgrade, \\ Faculty of Transport and Traffic Engineering, Belgrade
}

Original scientific paper

\begin{abstract}
The analysis of the suitability of applying multi-criteria ranking of road design variants places the emphasis on the danger of fixing the ranking results, by the impact of subjective factors, in the process of determining relevant criteria and their relative weights.

This danger is illustrated using two real examples.

In the first example, subjective factors did not have a decisive influence since all of the most significant technical exploitation economic and ecological indicators, determined in the appropriate study and project documentation, were taken into account while determining relevant criteria and their relative weights.

In the second example, subjective factors had a more decisive influence since all of the most significant technical exploitation economic and ecological indicators, determined in the appropriate study and project documentation, were not taken into account while determining relevant criteria and their relative weights.
\end{abstract}

Key words: Multi-criteria ranking, design variant, SAW method, AHP method, criteria, weights of criteria, internal rate of return IRR, NSV

\section{INTRODUCTION}

Multi-criteria analyses which, as part of mathematical sciences, belong to operational research, have found the application, in the role of a "tool", in the procedures of multi-criteria ranking (MCDM) of the variants of designed roads. Since 1957 numerous methods for conducting multi-criteria ranking have been developed. Some of them are: SAW (Simple Additive Weighting Method), TOPSIS (The Technique for Order of Preference by Similarity to Ideal Solution), ELECTRA (Elimination Et Choix Traduinsant Realite), PROMETHEE (A Preference Ranking Organization Method for Enrichment Evaluation), VIKOR, AHP (Analytic Hierarchy Process), etc.

\section{BASIC STEPS IN THE APPLICATION OF MULTI-CRITERIA RANKING OF ROAD DESIGNS}

Basic steps in the application of multi-criteria ranking in the procedures of choosing the optimal variant of the designed roads are:

Author's address: Ljubiša Kuzović, Engineering Academy of Serbia, Belgrade, Kneza Miloša 9

Paper received: 24.11.2014.

Paper accepted: 01.12.2014.
- The first step - determining the variants

- The second step - determining (the sizes of) basic indicators, which were previously defined in the appropriate study and project documentation, for the designed variants

Table 1. Basic matrix

\begin{tabular}{|c|c|c|c|c|}
\hline \multirow{2}{*}{$\begin{array}{l}\text { Basic } \\
\text { indicators } \\
(\mathrm{Xj})\end{array}$} & \multicolumn{4}{|c|}{$\begin{array}{l}\text { Sizes (values) of basic indicators by variants } \\
\text { (Vi) }\end{array}$} \\
\hline & V1 & V2 & $\ldots$ & $\mathrm{Vn}$ \\
\hline $\mathrm{X} 1$ & & & & \\
\hline $\mathrm{X} 2$ & & & & \\
\hline $\mathrm{X} 3$ & & & & \\
\hline ……......... & & & & \\
\hline $\mathrm{Xn}$ & & & & \\
\hline
\end{tabular}

- The third step - determining the relevant criteria

In this phase, the basic indicators are defined and transformed into the relevant criteria on the basis of which the multi-criteria ranking of the variants is conducted by applying some of the multi-criteria evaluation methods. 
- The fourth step - determining the relative weights of the relevant criteria

In the application of any of the multi-criteria ranking methods, the selected relevant criteria, and especially the allocation (assigning) of relative weights to the relevant criteria, have a significant influence on the results, in addition to the influence of the value of the basic indicators per variants defined in the appropriate study and project documentation. Considering the fact that subjective criteria have a significant influence on the selection of relevant criteria and on the allocation of relative weights to the selected criteria, multi-criteria ranking for the selection of the variant is best applied in the cases where differences between the variants are minimal, when measured by technical exploitation, economic and ecological indicators. This is because a very precise scale is necessary for the relative ranking of variants in the situations when the differences between them are minimal, and if it happens that their ranking has been influenced by a strong subjective factor, no big harmful consequences can emerge.

However, there are situations where there are significant differences between the values of the basic, technical exploitation, economic and ecological indicators according to which the advantage of some variant is evident. In these situations, in the process of applying multi-criteria ranking of variants and as a consequence of the pronounced influence of the subjective factor, there could be a danger of choosing a variant which is clearly worse according to all of the most significant technical exploitation, economic and ecological indicators, which would cause enormous, various and long-term damages. In the described situations, where one of the considered variants is evidently and clearly the most favourable according to the values of technical exploitation, economic and ecological indicators, "the expert" who demands the application of the multi-criteria ranking for selecting the variant is obviously an ignorant or has a bad intention to fix results according to the principle of white becoming black, and black becoming white. it is most frequently a combination of the lack of knowledge and bad intentions, since the one who knows little is more inclined to faking results.

Thus, in the application of multi-criteria variant ranking, the biggest importance should be given to determining the relevant criteria and assigning relative weights to the selected criteria, while the choice of the method of multi-criteria ranking has less significance.

This is why the SAW multi-criteria ranking method is the only method described in the further text.

Also, we have shown two numerical examples of variant ranking where the relative sequence (order) is noticeable and based on the values of the main and most significant technical exploitation, economic and ecological indicators:

- the first numerical example shows the practical application of the SAW method where subjective factors virtually had no influence on the ranking results;

- the second numerical example is based on the application of the AHP method and here subjective factors had the decisive and practically sole influence on the ranking results.

\section{SAW - SIMPLE ADDITIVE WEIGHTING METHOD}

This method is one of the most common and most frequently used methods in multi-criteria ranking. In order to use this method, it is essential to define relevant criteria and relative weights of the selected criteria. Prior to applying this method, it is necessary to normalize the values that some variants $V i$ take according to particular criteria (the value from the basis matrix $D$ ). Non-dimensional elements $r_{i j}$ of the normalized matrix $R$ are obtained in the following way:

- for the "benefits" criteria by the relation $r_{i j}=$ $x_{i j} / x_{\text {max }}$

- for the "costs" criteria by the relation $r_{i j}=x_{j m i n} / x_{i j}$, where $i$ represents the variant and $j$ represents the criterion.

The total number of points for particular variants is obtained when the value from the normalized matrix (R), which some of the variants take according to particular criteria, is multiplied by the corresponding weighting values of criteria (Wi). Thus obtained products, which relate to the particular variants, are added. The final result is the sum of these variants. The best variant is the one with the biggest sum total.

\section{A NUMERICAL EXAMPLE OF THE SAW METHOD FOR VARIANT RANKING, WHERE SUBJECTIVE FACTORS PRACTICALLY HAD NO INFLUENCE ON THE VARIANT RANKING RESULTS}

The main objective of showing the following numerical example is the detailed presentation of the SAW method application where subjective factors had no influence on ranking results.

The reason for this is the fact that the ranking brought to the selection of the criteria which represented the most significant, transformed technical exploitation, economic and ecological indicators; this brought to the ranking result by applying the SAW method which was identical to the result similarly evident through the basic, most important technical 
exploitation, economic and ecological indicators. This numerical example refers to the selection of the most favorable variant of the motorway Belgrade - Southern Adriatic on the stretch from Belgrade to Pozega.

(1) The first step - determining the variants to be compared

- V1 - Belgrade-Obrenovac-Ljig-Takovo-PreljinaPozega

- $\quad$ V2 - Belgrade-Obrenovac-Ub-Slovac-Cestobro dica-Pozega

- V3 - Belgrade-B.Potok-M.Pozarevac-Topola-Takovo-Pozeg

(2) The second step - determining the values of the most significant indicators per variants (see table 2)

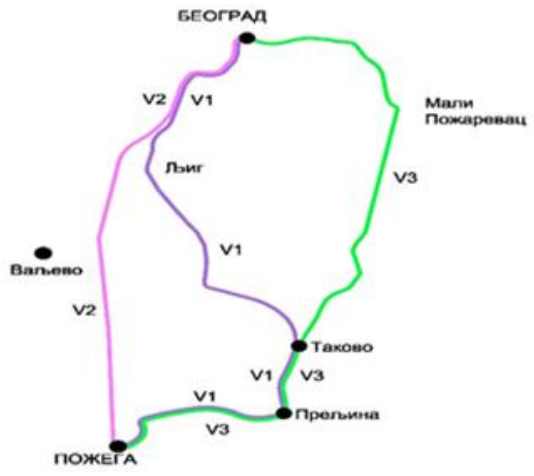

Figure 1 - Schematic representation of the motorway corridor Belgrade-Pozega variants

Table 2. Fulfilled basic matrix

\begin{tabular}{|l|l|l|l|l|l|}
\hline \multicolumn{2}{|l|}{ Basic indicators $\left(\mathrm{X}_{\mathrm{j}}\right)$} & \multirow{2}{*}{$\begin{array}{l}\text { Unit of } \\
\text { measure }\end{array}$} & & \multicolumn{3}{l|}{ Values of basic indicators by variants $\left(\mathrm{V}_{\mathrm{i}}\right)$} \\
\cline { 5 - 6 } & $\mathrm{V}$ & $\mathrm{V}_{1}$ & $\mathrm{~V}_{2}$ & $\mathrm{~V}_{3}$ \\
\hline $\mathrm{X}_{1}$ & Length of motorway route $(\mathrm{L})$ & $\mathrm{km})$ & 144.055 & 126.650 & 143.144 \\
\hline $\mathrm{X}_{2}$ & $\begin{array}{l}\text { Total construction and operating costs discounted to } \\
\text { the first year }\left(\sum T\right)\end{array}$ & $\begin{array}{l}\text { (million } \\
\text { dinars) }\end{array}$ & $1,675,798$ & $1,684,849$ & $1,751,365$ \\
\hline $\mathrm{X}_{3}$ & Internal Rate of Return (ISR) & $(\%)$ & 13.30 & 13.39 & 10.60 \\
\hline $\mathrm{X}_{4}$ & Spatial urbanistic and ecological aspects & (points) & 99.30 & 98.30 & 97.60 \\
\hline
\end{tabular}

(3) The third step - determining the criteria by which variants were ranked

- $\mathrm{X}_{1}-\mathrm{L}-$ length of motorway route $(\mathrm{km})(-){ }^{(*)}$

- $\mathrm{X}_{2}-\sum T^{-}$criteria of total construction and operating costs discounted to the first year $\left(10^{6}\right)(-){ }^{(*)}$

- $\mathrm{X}_{3}-$ ISR - Internal Rate of Return $(\%)(+)^{(* *)}$

- $\mathrm{X}_{4}-$ spatial urbanistic and ecological aspects (points) $(+)^{(* *)}$

(4) The fourth step - forming base matrix (D) and nondimensional matrix

Table 3. Base matrix (D)

\begin{tabular}{|l|l|l|l|l|}
\hline \multirow{2}{*}{ Variant } & \multicolumn{3}{|l|}{ Criterion } & \multicolumn{2}{l|}{} \\
\cline { 2 - 5 } & $\mathrm{X} 1(-)$ & $\mathrm{X} 2(-)$ & $\mathrm{X} 3(+)$ & $\mathrm{X} 4(+)$ \\
\hline V1 & 144.055 & $1,675,798$ & 13,30 & 99.3 \\
\hline V2 & 126.650 & $1,684,849$ & 13,39 & 98.3 \\
\hline V3 & 143.144 & $1,751,365$ & 10,60 & 97.6 \\
\hline
\end{tabular}

$$
\begin{aligned}
& V_{1}=\sum_{i=1}^{4} r_{1 j} \cdot W_{j}=0.88 \cdot 0.15+1.00 \cdot 0.30+0.99 \cdot 0.35+1.00 \cdot 0.20=\underline{0.9785} \\
& V_{2}=\sum_{i=1}^{4} r_{2 j} \cdot W_{j}=1.00 \cdot 0.15+0.99 \cdot 0.30+1.00 \cdot 0.35+0.99 \cdot 0.20=\underline{0.9950}
\end{aligned}
$$

$\left(^{*}\right)$ - "Costs" (-) criterion. The best variant is one with the lowest value according to this criterion

${ }^{(* *)}$ - "Benefits" $(+)$ criterion. The best variant is one with the highest value according to this criterion
Table 4. Non-dimensional matrix $(R)$

\begin{tabular}{|r|r|r|r|r|}
\hline \multicolumn{5}{|c|}{ Elements $r_{i j}$ of non-dimensional matrix $(R)$} \\
\hline \multirow{2}{*}{ Variant } & \multicolumn{4}{|c|}{ Criterion } \\
\cline { 2 - 5 } & $\mathrm{X}_{1}(-)$ & $\mathrm{X}_{2}(-)$ & \multicolumn{1}{|c|}{$\mathrm{X}_{3}(+)$} & $\mathrm{X}_{4}(+)$ \\
\hline$V_{l}$ & 0.88 & 1.00 & 0.99 & 1.00 \\
\hline $\mathrm{V}_{2}$ & 1.00 & 0.99 & 1.00 & 0.99 \\
\hline $\mathrm{V}_{3}$ & 0.89 & 0.96 & 0.80 & 0.98 \\
\hline
\end{tabular}

(5) The fifth step - determining weights of certain criteria

Taking into account the importance of the basic technical exploitation, economic and environmental indicators, weights $\left(W_{i}\right)$ of certain criteria were defined.

$\mathrm{W}_{1}=0.15 ; \mathrm{W}_{2}=0.30 ; \mathrm{W}_{3}=0.35 ; \mathrm{W}_{4}=0.20$

( $\sum W_{j}=1$-weights defined by method of ranking)

(6) The sixth step - performing the calculation of weights values for variants 


$$
V_{3}=\sum_{i=1}^{4} r_{3 j} \cdot W_{j}=0.89 \cdot 0.15+0.96 \cdot 0.30+0.80 \cdot 0.35+0.98 \cdot 0.20=\underline{0.8975}
$$

(7) The seventh step - determining the relative order of the considered variants

Based on the obtained results, the best variant is $V_{2}$ $(0,9950)$ and the relative order of the considered variants is as follows (following):
I) $\mathrm{V}_{2} \quad(0.9950)$
II) $\mathrm{V}_{1}(0.9785)$
III) $\mathrm{V}_{3}(0.8975)$

\section{A NUMERICAL EXAMPLE OF APPLYING THE AHP METHOD FOR VARIANT RANKING, WHERE SUBJECTIVE FACTORS HAD THE DECISIVE (SOLE) INFLUENCE ON THE RESULTS OF VARIANT RANKING}

The main goal of showing the following numerical example is to present the application of multi-criteria ranking (AHP method) where the variant of the

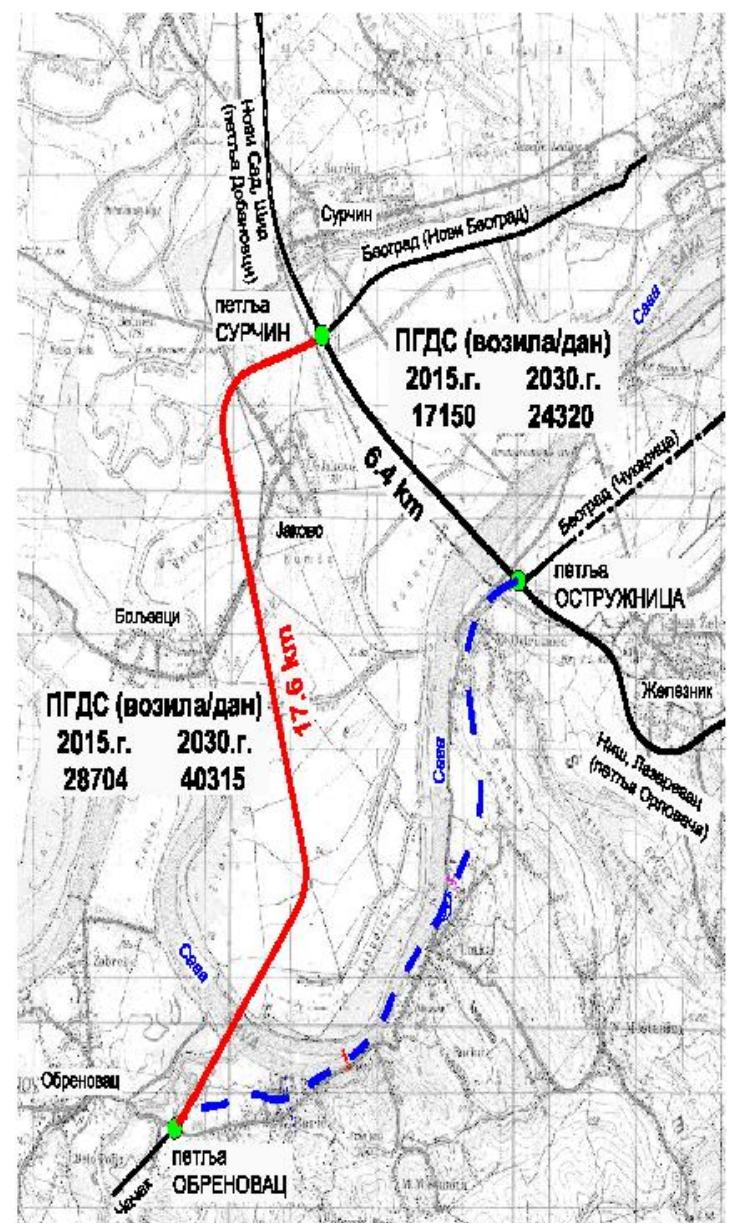

Variant Surcin-Obrenovac (on the left bank of the Sava River) Tconstruction: $166.391 .188 €$ designed motorway was selected exclusively with the maximum influence of subjective factors, and where it was "scientifically" proved how black becomes white and white becomes black.

This numerical example refers to the selection of the variant of the designed motorway Belgrade South Adriatic on the strech between the Belgrade bypass and Obrenovac.

(1) The first step - determining the variants to be compared

These are the variants of the designed motorway:

- V1 - on the RIGHT bank of the Sava River from Ostruznica to the Obrenovac interchange

- $\quad \mathrm{V} 2$ - on the LEFT bank of the Sava River from the Surcin interchange to the Obrenovac interchange

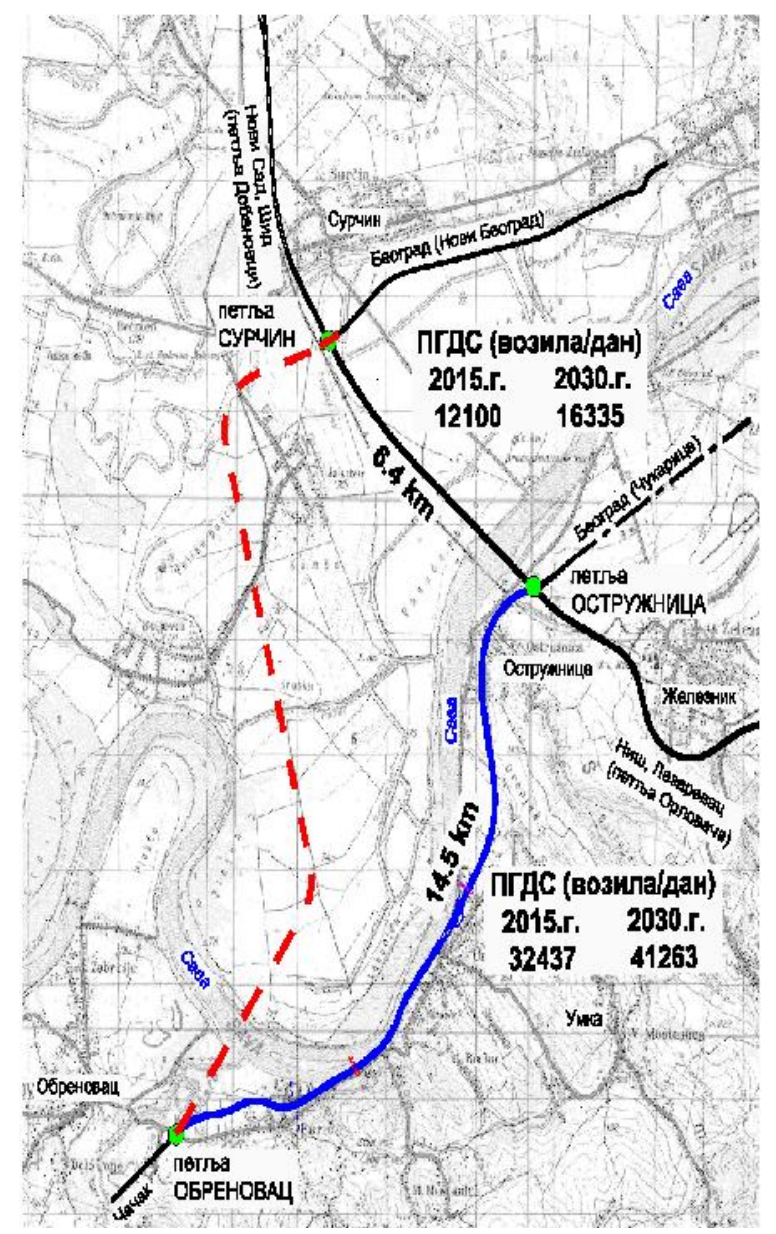

Variant Ostruznica-Obrenovac (on the right bank of the Sava River) Tconstruction: $136.850 .000 €$

Figure 2 - Variant positions schematic representation of the future motorway from Belgrade bypass to Obrenovac

(2) The second step - determining the values of the most significant indicators per variants 
Table 5. Determining the values of the most significant indicators per variants

\begin{tabular}{|c|c|c|c|c|}
\hline \multirow{2}{*}{\multicolumn{2}{|c|}{ Basic indicator $\left(\mathrm{X}_{\mathrm{j}}\right)$}} & \multirow{3}{*}{$\begin{array}{l}\text { Unit of measure } \\
(\mathrm{km})\end{array}$} & \multicolumn{2}{|c|}{ Values of basic indicators by variants $\left(\mathrm{V}_{\mathrm{i}}\right)$} \\
\hline & & & \multirow{2}{*}{$\begin{array}{l}\mathrm{V}_{1} \text { (The RIGHT bank } \\
\text { of the Sava River) } \\
14.5\end{array}$} & \multirow{2}{*}{ 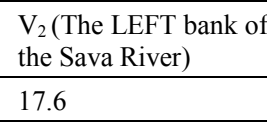 } \\
\hline $\mathrm{X}_{1}$ & Length of designed motorway route & & & \\
\hline $\mathrm{X}_{2}$ & Orientation of dominant traffic flows & $(\%)$ & 60 & 40 \\
\hline $\mathrm{X}_{3}$ & $\begin{array}{l}\text { Traffic volume on the motorway in the first year } \\
\text { (ПГДС) }\end{array}$ & (veh/day) & 32400 & 28700 \\
\hline $\mathrm{X}_{4}$ & The costs of motorway construction & $(€)$ & $136,850,000$ & $166,390,000$ \\
\hline $\mathrm{X}_{5}$ & $\begin{array}{l}\text { The costs of landslides rehabilitation } \\
\text { Duboko construction costs of urban road Surcin- } \\
\text { Novi Beograd, which are not covered by the } \\
\text { construction costs of motorway route }\end{array}$ & $(€)$ & 0 & $119,200,000$ \\
\hline $\mathrm{X}_{6}$ & Economic Internal Rate of Return (EISR) & $(\%)$ & 35.0 & 24.8 \\
\hline $\mathrm{X}_{7}$ & Financial Internal Rate of Return (FISR) & $(\%)$ & 10.0 & 6.0 \\
\hline $\mathrm{X}_{8}$ & $\begin{array}{l}\text { The number of years in wich invested capital } \\
\text { returns from toll revenue }\end{array}$ & (years) & $15-20$ & $25-30$ \\
\hline
\end{tabular}

According to the following illustration of the values of the most significant technical exploitation, economic and ecological indictors per variants, determined in the study and project documentation processed on the level of Conceptual Design, it is apparent that the treated variants significantly differ according to numerous characteristics and that one of the variants has the distinct advantage regarding the most important technical exploitation, economic and ecological indicators.

This means that in such cases the application of multi-criteria ranking only has the aim to fix ranking results by the inappropriate influence of subjective factors.

(3) The third step - determining the criteria by which variants were ranked

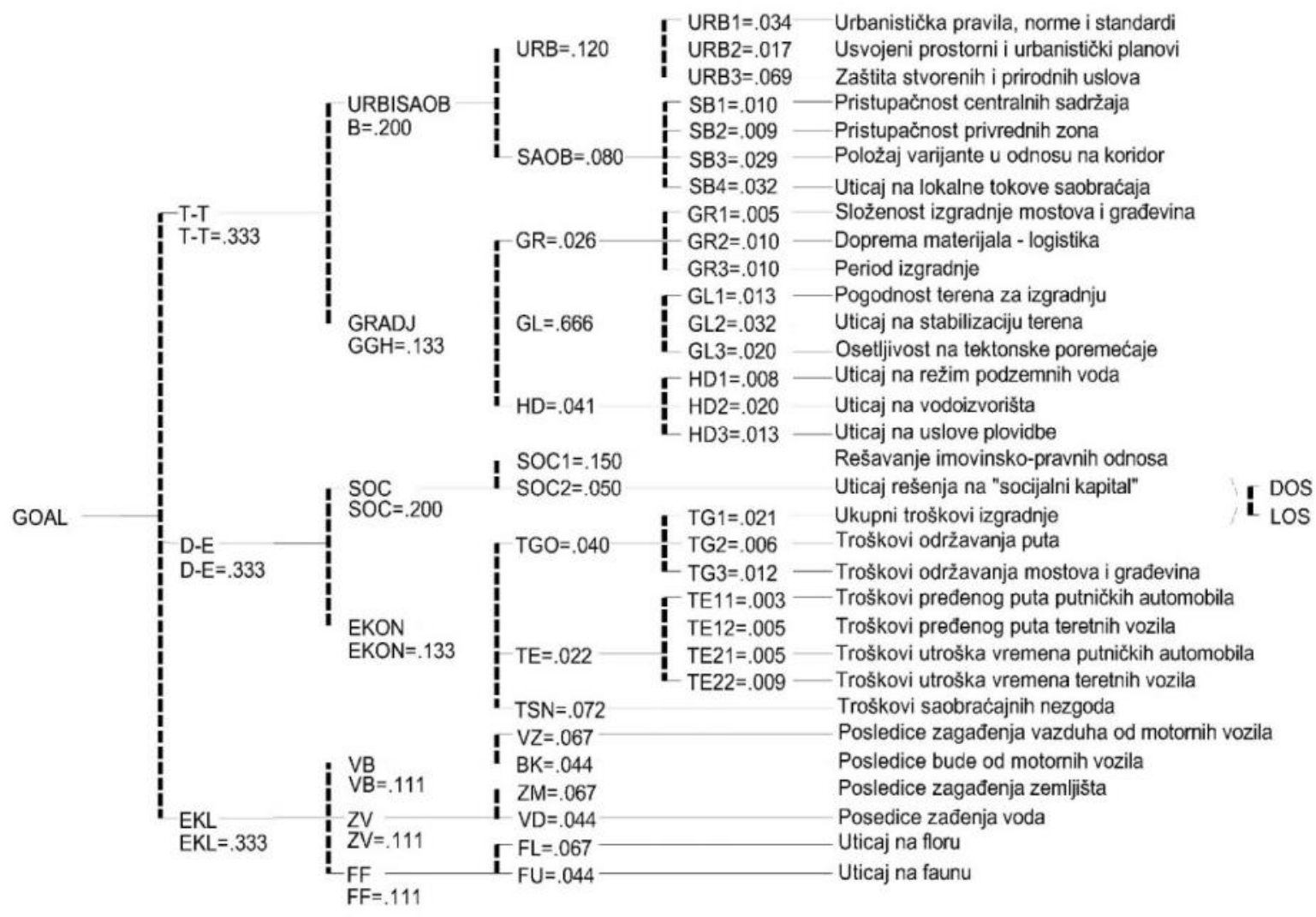

Figure 3 - The criteria by which variants were ranked 
Determining the basic criteria and fragmenting them into over 30 subcriteria of dubious importance, while omitting and blurring some very important ones (EISR, FISR, the number of years needed for the capital invested in the motorway to be returned through the toll payment, costs of maintaining the relevant road networks etc.), clearly signalizes that the main goal of applying the AHP method of multi-criteria ranking is to "SCIENTIFICALLY" prove the selection of the highway variant Surcin - Obrenovac, although this variant is clearly worse than the variant Ostruznica Beograd according to all of the most significant technical exploitation, economic and ecological indicators).

(4) The fourth step - conducting the pairwise comparison of all the variants on all the levels of the AHP model.

- Pairwise comparison on the first level - the level of main criteria

On this level, all the project participants compared technical and technological (T-T), social and economic (S-E) and ecological (ECL) criteria. On the basis of disussions and consideration of the results of these discussions it was stated that these three groups of criteria were equally important. One of the conclusions of the disussion was that this should be the premise and that the final analysis of results should point out to which extent the change of these criteria would influence the final result.

- Pairwise comparison on the second level

Experts, members of the work team, people from the field to which the considered level of comparison belonged, took part in each of the following levels of the pairwise comparison process. Technical and technological (T-T) criteria were divided into two main groups: urbanistic and traffic (URB\&TRAFF) and construction and geological and hydrological (CGH). Social and economic criteria (S-E) were also put into two main groups: sociological (SOC) and economic (ECON). In the field of ecology (ECOL) the criteria were divided into three main groups: consequences of air pollution and consequences of vehicle noise (AN), soil and water pollution (SW) and flora and fauna destruction (FF).

\section{- Pairwise comparison on the third level}

On this level, as it can be seen in the picture (AHP diagram), it was necessary to conduct the pairwise comparison of those criteria which emerged as the consequence of the criterion division on the second level. Thus the criterion group URB\&TRAFF was divided into urbanistic (URB) and traffic subcriteria (TRAFF).

On this level there is the division of sociological criteria (SOC) into the subcriteria of solving property rights (SOC1) and the influence on the so-called Social capital (SOC2).

On this level, ecological criteria were divided into subcriteria. The air and noise group (AN) was divided into the subcriteria of air pollution (AP) and consequences of noise pollution $(\mathrm{CN})$. The group of criteria referring to soil and water pollution (SW) was divided into the subcriteria of soil pollution (SP) and water pollution (WP).

\section{- Pairwise comparison on the fourth level}

On this level it is necessary to conduct the pairwise comparison of those criteria which emerged as the consequence of the criterion division on the third level. Urbanistic criteria (URB) were divided into the following subcriteria: urbanistic norms, regulations and standards (URB1), attitude towards the adopted regional and urbanistic plans (URB2) and the protection of human-made and natural values (URB3).

The next division on this level is the division of traffic criteria (TRAFF) into the subcriteria of the accessibility of central attractions (TR1), the accessibility of economic zones (TR2), the variant's position in relation to the corridor E-763 (TR3) and in relation to the local traffic flows (TR4).

Furthermore, the construction criterion (Con) was divided into the subcriteria of the complexity of constructing bridges and buildings (CON1), supplying the construction material - logistics (CON2) and the period of the section's construction (CON3).

Geological criteria (GL) were divided into the next subcriteria: the constructional suitability of the terrain (GL1), the influence on terrain stabilization (GL2) and the sensitivity to tectonic disturbance (GL3).

The criteria in the field of hydrology and hydrotechnical engineering (HD) were divided into the following subcriteria: the influence on underground water regime (HD1), the influence on the water sources (HD2) and influence on sailing conditions (HD3).

The criteria referring to the costs of the variant's construction and maintenance (CCM) were separated into the subcriteria: total costs of the section construction (CC1), costs of maintaining the highway section $(\mathrm{CC} 2)$ and costs of maintaining the bridges and buildings (CC3).

The last division on this level was the division of the exploitation costs criterion (EC) into the next subcriteria: the costs of the distances covered by passenger vehicles (EC11), the costs of the consumed time by passenger vehicles (EC12), the costs of the distances covered by freight vehicles (EC21) and the costs of the consumed time by freight vehicles (EC22).

- Pairwise comparison on the fifth level 
In the fifth phase the comparison of the alternatives according to the superior criteria was carried out.

The described process of pairwise comparison on all the levels using the AHP method openly announced the decisive influence of subjective factors on the selection of the variant, in order to give advantage to the variant of the motorway Surcin-Obrenovac on the basis of the most (fictitious) artificially determined subcriteria of dubious significance.

(5) The fifth step - comparing variants according to superior criteria

After the given remarks in the third and fourth step, due to the crucial influence of subjective factors, the variant Surcin - Obrenovac was given precendence according to 24 subcriteria of doubtful significance, while the variant Ostruznica-Obrenovac was given advantage on the basis of 8 subcriteria.

\section{THE ANALYSIS OF THE NEGATIVE EFFECTS WHICH WILL BE BROUGHT BY SELECTING THE MOTORWAY VARIANT SURCIN- OBRENOVAC INSTEAD OF THE MOTORWAY VARIANT OSTRUZNICA- OBRENOVAC}

The analysis of the most significant technical and technological, economic and ecological indicators per variants, determined in the study and project documentation for both variants, has shown that the construction of the motorway variant Surcin - Obrenovac instead of the variant Ostruznica - Obrenovac would cause numerous negative cosequences, such as:

1. Total expenses from the budget of the republic of serbia for the construction of motorway surcinobrenovac instead of the motorway Ostruznica-Obrenovac will be higher by approximately $149.200 .000 €$.

The above-mentioned amount includes:

a) Approximately $30.000 .000 €$ in terms of the motorway construction by the LEFT bank of the Sava River from SURCIN to Obrenovac, on the basis of both Conceptual Designs of the motorway from the Belgrade bypass by the "right" and "left" bank of the Sava River which were audited by the same Audit Committee;

b) Approximately $80.000 .000 €$ for restoring the landslide site of Umka-Duboko and adjusting the Sava River's hydraulic and sailing parameters to the European standards, which are included in the price of constructing the motorway by the RIGHT bank of the Sava River, while the Conceptual Design was audited by the same Republic Audit Committee;

c) Approximately 39.200.000€ for the expenses of the urban road construction, which would connect the motorway from Surcin to Novi Beograd. The given cost is included in the Feasibility Study for the construction of the motorway by the left bank of the Sava River, which was audited by the same Republic Audit Committee.

2. Regarding the motorway variant by the left bank of the Sava, from Surcin to Obrenovac, all of the most important technical exploitation, economic and ecological parameters are clearly less favourable than the variant of the motorway by the right bank of the Sava from Ostruznica to Obrenovac:

d) The road will be longer by around 9,5 $\mathrm{km}$ for more than $60 \%$ of vehicles in the traffic flow.

e) The traffic flow will be smaller by around $13 \%$, which will remain on the existing, less safe roads 22 (M22) and 26 (M19).

f) In the process of the motorway construction, the road 26 (M19) from Umka to Obrenovac will not be brought into the quality exploitation state.

g) In the process of the motorway construction, the hydraulic and sailing parameters of the Sava River will not be adjusted to the European standards.

h) In the process of the motorway construction, the landslide Umka-Duboko will not be restored, which means that around 500 facilities will be in danger of falling in and around 200 hectares of the devastated land will not be restored into the quality building land.

i) The costs of vehicle operating will rise by more than $300.000 .000 €$ in the period of thirty years.

j) The costs of the travelling time of passengers in passenger vehicles and buses will rise by more than $50.000 .000 €$ in the period of thirty years.

k) The costs of maintaining the motorway and part of the existing road network will rise by more than $10.000 .000 €$ in the period of thirty years.

1) More than 120 hectares of farmland will be destroyed for all the future time.

\section{THE NEGATIVE CONSEQUENCES IN THE IMPLEMENTATION AND OPERATION OF THE MOTORWAY VARIANTS SELECTED TROUGH MCA UNDER THE DECISIVE INFLUENCE OF SUBJECTIVE FACTORS}

The analysis of the most significant technical and technological, economic and ecological indicators per variants, determined in the study and project documentation for both variants, has shown that the construction of the motorway variant Surcin - Obrenovac instead of the variant Ostruznica - Obrenovac would cause numerous negative cosequences, such as:

- The higher construction costs by over $20 \%$.

- Costs of repairs of landslide Umka will not be a part of the motorway construction cost. 
- Improved hydraulic and navigation parameters of the Sava river in line with European standards will not be a part of the motorway construction cost.

- There will be no indirect effect of motorway construction on improved road conditions to state road first rank number 26 (M19).

- Road will be longer about $9.5 \mathrm{~km}$ for $60 \%$ of vehicles in the traffic flow.

- There will be less traffic flow on the motorway for about $13 \%$ (in the first year of operation). This traffic flows will remain on existing roads which is less safe road mark 22 (M22) and road mark 26 (M19).

- It will be much higher Road user cost of using the highway (vehicle operating costs, time costs of passengers and cargo, accident costs, maintenance costs of the road network).

- It will be required significantly longer concession period for the return of capital invested in highway trough toll collection;

- Jeopardize the water-source (water wells) located not left bank of the Sava river.

- It will destroys for all time over 120 hectares of agricultural land.

\section{REFERENCES:}

[1] Kuzović, L., Ujdur B., Aleksić, B. Ulaganje u varijantu autoputa Surčin - Obrenovac, umesto u varijantu Ostružnica - Obrenovac izazvalo bi nesagledivo velike i dugoročne ekonomske gubitke. Put i saobraćaj, 60(3), 5-10, 2014.

[2] Kuzović, L., Aleksić, B. Albreht I., Otovic S. Kritički osvrt na ulogu studija opravdanosti pri odlučivanju o racionalnom ulaganju u projekte puteva. Put i saobraćaj, 60(3), 11-14, 2014.

[3] Hwang C. L., Yon K. Multiple Attribute Decision Making - Methods and Applications, SpringerVerlag, Berlin, Heidelborg, New York, 1981.

[4] European Commission Cost-Benefit and multi-criteria analysis for new road construction, 1996.

[5] Instite of Transport CIP. Conceptual design with feasibility study of the motorway E-763 Belgrade - Pozega, the route by the left bank of the Sava river, Feasibility study, book 20, 2011.

[6] Public Enterprise "Roads of Serbia". Conceptual design E-763 Belgrade - Ljig - Pozega, book 17, Feasibility study, Belgrade, 2006.

[7] The Road Association of Serbia and The Engineering Academy of Serbia. The monograph entitled "Connecting the motorway Belgrade - Southern Adriatic with Corridor $\mathrm{X}$ and basic road network of Belgrade“, Belgrade, 2010.

[8] *** The attitudes of experts of the Road Association of Sebia, Engineering Academy of Serbia and The Association of Civil Engineers of Serbia regarding the rout selection of the motorway Belgrade Southern Adriatic from Belgrade bypass to Obrenovac, Belgrade, 2012.

[9] *** Multi-criteria evaluation of variants of the motorway Belgrade - Southern Adriatic in the administrative area of Belgrade, Corridors of Serbia d.o.o, Belgrade, 2013.

$[10]^{* * *}$ The conclusions of the discussions held in The Engineering Academy of Serbia 9.7.2013. „The design of motorway Belgrade - Southern Adriatic from Belgrade bypass to Obrenovac", 2013.

\section{REZIME}

\section{PRIMENA VIŠEKRITERIJUMSKE ANALIZE U VREDNOVANJU PROJEKATA PUTEVA}

U analizi podobnosti primene višekriterijumskog rangiranja projektnih varijanti puteva, naglasak je dat na opasnost da se delovanjem subjektivnih faktora, pri određivanju merodavnih kriterijuma i njihovih relativnih težina, može nameštati rezultat rangiranja.

Ova opasnost je ilustrovana kroz dva realna primera.

U prvom primeru subjektivni faktori nisu odlučujuće uticali, jer su, pri utvrđivanju merodavnih kriterijuma $i$ njihovih relativnih težina, uvažavani najznačajniji tehničko-eksploatacioni, ekonomski $i$ ekološki pokazatelji, koji su utvrđeni u odgovarajućoj studijsko-projektnoj dokumentaciji.

U drugom primeru subjektivni faktori su odlučujuće uticali, jer, pri utvrđivanju merodavnih kriterijuma i njihovih relativnih težina, nisu uvažavani najznačajniji tehničko-eksploatacioni, ekonomski i ekološki pokazatelji, koji su utvrđeni u odgovarajućoj studijsko-projektnoj dokumentaciji.

Ključne reči: višekriterijumsko rangiranji, SAW metod, AHP metod, kriterijumi, težine kriterijuma, interna stopa ISR, NSV, varijanta, projekat 